\title{
A comparative study of serum magnesium levels in preterm labour and term labour
}

\author{
Malathi T.*, Sowmya Sampurna Maddipati
}

Department of Obstetrics and Gynecology, Kempegowda Institute of Medical Sciences, Bengaluru, Karnataka, India

Received: 26 May 2020

Revised: 09 June 2020

Accepted: 03 July 2020

\section{*Correspondence:}

Dr. Malathi T.,

E-mail: sowmya.dr11@gmail.com

Copyright: (C) the author(s), publisher and licensee Medip Academy. This is an open-access article distributed under the terms of the Creative Commons Attribution Non-Commercial License, which permits unrestricted non-commercial use, distribution, and reproduction in any medium, provided the original work is properly cited.

\section{ABSTRACT}

Background: The objective of present study was to measure the serum magnesium levels in preterm labor patients, to measure the serum magnesium levels in term labor patients and to correlate the serum magnesium levels in preterm and term labor patients.

Methods: It is a prospective case control study conducted in the department of obstetrics and gynecology, KIMS hospital and research Centre, Bengaluru, Karnataka, India. A venous blood sample is drawn from patients admitted to labor room who fulfill the inclusion and exclusion criteria out of which 50 patients belong to the Group-A (preterm labor) and 50 patients belong to Group-B (term labor). Serum magnesium level is measured in both the groups.

Results: Women with preterm labor had a significantly reduced serum magnesium level with a mean serum magnesium level of $1.59 \mathrm{mg} / \mathrm{dl}$ with a SD of 0.83 whereas the patients with term labor had a mean serum magnesium level of $2.55 \mathrm{mg} / \mathrm{dl}$ with a SD of 0.40 . The difference of serum magnesium levels observed between the study population and control population is independent of factors like maternal age, parity, gestational age, and socioeconomic factors. In this study, it is found that serum magnesium levels are lower in early and late preterm compared to preterm between $33-34+6$ weeks.

Conclusions: Serum magnesium level can be used as a predicting tool for preterm labor. Preterm labor can be avoided by simple supplementation of Magnesium which might provide an easy and inexpensive means to decrease the problems related to preterm labor. There is a further scope for research on serum magnesium levels based on gestational age.

Keywords: Preterm labor, Serum magnesium level, Term labor

\section{INTRODUCTION}

Preterm birth is defined as birth between the age of viability i.e., between 28 weeks and 37 completed weeks of gestation. Preterm births had been given more attention as it is the major leading cause of perinatal and neonatal mortality and morbidity comprising to $50 \%$ and there are many short-term and long-term complications associated with low birth weight due to preterm. ${ }^{1}$ Although all births before 37 weeks of gestation are considered premature, births before 32 weeks of gestation account for most neonatal deaths and disorders. ${ }^{1}$
Incidence of preterm labor in India is $5-10 \%$ leading to $70 \%-80 \%$ of perinatal deaths. Late preterm births (34 weeks to $36+6$ days) account for about $74 \%$ of all preterm births while the early preterm births ( $<32$ weeks) comprise $2 \%$ of all births and remained constant during the last two decades. ${ }^{2,3}$

The causes of preterm labor are not completely known, in $50 \%$ cases it is spontaneous and idiopathic, although several potential risk factors have been identified. The main among them is premature rupture of membranes (PROM) which is up to $30 \%$ and another $15-20 \%$ is 
secondary to conditions like multiple pregnancy, polyhydramnios, infection, uterine anomalies, cervical incompetence, antepartum hemorrhage, hypertensive disorder of pregnancy, anemia, smoking, fetal anomalies and IUD, etc. It is also related to socioeconomic status and geographic location. ${ }^{4-6}$

Beside these etiologies, preterm labor is also due to a biochemical alteration of body function at the cellular level of trace elements such as magnesium, which is the second most abundant intracellular cation after potassium. ${ }^{7,8}$ It plays number of vital physiological and biochemical roles; intracellular ionized magnesium is essential for nerve conduction and muscle contraction. ${ }^{9}$ The inhibitory effect of magnesium on preterm labor causes antagonism of calcium mediated uterine contractions, and hence, it's is used as a tocolytic. ${ }^{10}$

The objective of this study was to prevent morbidity and mortality due to preterm births, there should be more emphasis on prediction and prevention of preterm labor. Hence this study is undertaken to evaluate magnesium levels in preterm labor and its implication in prevention of preterm labor.

\section{METHODS}

This was a prospective case control study conducted at department of obstetrics and gynecology, KIMS Hospital and Research Centre, Bangalore, Karnataka, India with women coming in preterm labor and in term labor. A total number of 100 women will be selected by consecutive sampling method for the study and those who fulfill the exclusion and inclusion criteria with consecutive sampling. The study duration was 18 months.

Group A (cases): 50 cases with preterm labor [between 28 weeks to $36+6$ weeks] of gestation.

Group B (controls): 50 controls with term labor that is after 37 completed weeks of gestation.

\section{Inclusion criteria}

- Patients with Singleton gestation

- Patients with preterm onset of labour [between 28 weeks and $36+6$ weeks of gestation]

- Patients in active labour

- Patients with intact fetal membranes.

\section{Exclusion criteria}

- Patients with previous history of recurrent abortions and preterm delivery

- Patients with recurrent UTI

- Patients with pre-eclampsia, polyhydramnios, ante partum hemorrhage, cervical incompetence or any uterine malformations, or patients who are known cases of hyper bilirubinemia, hemolytic disorders, hyperlipidemias, Waldenstrom's macroglobulinemia
- Fetal congenital malformations, intra uterine death

\section{Method of the test}

Colorimetric end point method. (in vitro test for the quantitative determination of magnesium in hu-man serum on Roche/Hitachi COBAS C systems).

\section{Principle of the test}

In alkaline solution, magnesium forms a purple com-plex with xylidyl blue, Diazonium salt. The magnesium concentration is measured photometrically via the decrease in the xylidyl blue absorbance.

\section{Sample collection}

A $2 \mathrm{ml}$ of venous blood is drawn from the cases and controls to evaluate the serum magnesium level at the time of admission to labor ward. The serum magnesium analysis is done in the laboratory by using xylidyl blue calorimetric method. The reference value for normal serum magnesium level is 1.6-2.6 mg/dl. As the sample collected is serum, EDTA should be avoided as it may give increased results.

\section{Statistical analysis}

Descriptive and inferential statistical analysis has been carried out in the present study. ${ }^{11-14}$ Results on continuous measurements are presented on Mean \pm SD (Min-Max) and results on categorical measurements are presented in Number (\%). Significance is assessed at $5 \%$ level of significance.

The following assumptions on data is made, Assumptions: 1. Dependent variables should be normally distributed, 2. Samples drawn from the population should be random, Cases of the samples should be independent

Student t-test (two tailed, independent) has been used to find the significance of study parameters on continuous scale between two groups (Inter group analysis) on metric parameters. Analysis of variance (ANOVA) has been used to find the significance of study parameters between three or more groups of patients

Chi-square/Fisher exact test has been used to find the significance of study parameters on categorical scale between two or more groups, non-parametric setting for qualitative data analysis. Fisher exact test used when cell samples are very small.

\section{Significant figures}

- $\quad+$ Suggestive significance ( $\mathrm{p}$ value: $0.05<\mathrm{p}<0.10)$

- Moderately significant ( $p$ value: $0.01<p \leq 0.05$ )

- $\quad * *$ Strongly significant ( $\mathrm{p}$ value: $\mathrm{p} \leq 0.01$ ). 


\section{Statistical software}

The statistical software namely SPSS 18.0, and R environment ver.3.2.2 were used for the analysis of the data and Microsoft word and excel have been used to generate graphs, tables etc.

\section{RESULTS}

In this study, majority of the patients belong to the age group between 20-30 years in both the groups. The mean age group among Group A patients is $24.70 \pm 3.64$ and the mean age group among Group B is $25.84 \pm 4.05$ and the mean age of the total patients included in the study is $25.27 \pm 3.87$ (Table 1). The youngest patient included in the study is 19 years and the eldest is 35 years.

Table 1: Age distribution of patients studied.

\begin{tabular}{|llll|}
\hline $\begin{array}{l}\text { Age in } \\
\text { years }\end{array}$ & Group A & Group B & Total \\
\hline$<20$ & $2(4 \%)$ & $3(6 \%)$ & $5(5 \%)$ \\
\hline $20-30$ & $44(88 \%)$ & $41(82 \%)$ & $85(85 \%)$ \\
\hline$>30$ & $4(8 \%)$ & $6(12 \%)$ & $10(10 \%)$ \\
\hline Total & $50(100 \%)$ & $50(100 \%)$ & $100(100 \%)$ \\
\hline Mean \pm SD & $24.70 \pm 3.64$ & $25.84 \pm 4.05$ & $25.27 \pm 3.87$ \\
\hline
\end{tabular}

Samples are age matched with $\mathrm{p}=0.142$, student $\mathrm{t}$-test.

Table 2: Gravida distribution of patients in two groups studied.

\begin{tabular}{|llll|}
\hline Gravida & Group A & Group B & Total \\
\hline 1 & $26(52 \%)$ & $25(50 \%)$ & $51(51 \%)$ \\
\hline 2 & $13(26 \%)$ & $15(30 \%)$ & $28(28 \%)$ \\
\hline 3 & $6(12 \%)$ & $7(14 \%)$ & $13(13 \%)$ \\
\hline 4 & $5(10 \%)$ & $3(6 \%)$ & $8(8 \%)$ \\
\hline Total & $50(100 \%)$ & $50(100 \%)$ & $100(100 \%)$ \\
\hline
\end{tabular}

$\mathrm{p}=0.915$, not significant, fisher exact test.

Table 3: POG distribution of patients in Group A.

\begin{tabular}{|ll|}
\hline POG & Group A \\
\hline $28-32+6$ weeks & $13(26.0 \%)$ \\
\hline $33-34+6$ weeks & $5(10.0 \%)$ \\
\hline $35-36+6$ weeks & $32(64.0 \%)$ \\
\hline Total & $50(100 \%)$ \\
\hline
\end{tabular}

Majority of the patients included in this study belong to primigravida's which is $51 \%$ (Table 2).

Table 3 determines the number of patients in Group A based on the gestational age. Among the patients in Group A, majority of the patients that is $64 \%$ belong to the gestational age of 35 to $36+6$ weeks (Table 3 ).

According to this graph there is no significant difference in socio-economic status among both the groups. The results were similar to Khani et al, study and Shahid et al, study (Table 4).
Table 4: Socio economic status distribution of patients in two groups studied.

\begin{tabular}{|lll|l|}
\hline $\begin{array}{l}\text { Socio economic } \\
\text { status }\end{array}$ & Group A & Group B & Total \\
\hline Lower middle & $21(42 \%)$ & $22(44 \%)$ & $43(43 \%)$ \\
\hline Upper lower & $6(12 \%)$ & $6(12 \%)$ & $12(12 \%)$ \\
\hline Upper middle & $23(46 \%)$ & $22(44 \%)$ & $45(45 \%)$ \\
\hline Total & $50(100 \%)$ & $50(100 \%)$ & $100(100 \%)$ \\
\hline
\end{tabular}

Table 5: Serum magnesium level among the two groups.

\begin{tabular}{|llll|}
\hline $\begin{array}{l}\text { Serum } \\
\text { magnesium }\end{array}$ & Group A & Group B & Total \\
\hline$<1.6$ & $26(52 \%)$ & $0(0 \%)$ & $26(26 \%)$ \\
\hline $1.6-2.0$ & $3(6 \%)$ & $4(8 \%)$ & $7(7 \%)$ \\
\hline $2.0-2.5$ & $12(24 \%)$ & $22(44 \%)$ & $34(34 \%)$ \\
\hline$>2.5$ & $9(18 \%)$ & $24(48 \%)$ & $33(33 \%)$ \\
\hline Total & $50(100 \%)$ & $50(100 \%)$ & $100(100 \%)$ \\
\hline
\end{tabular}

Table 5 represents the serum magnesium levels among different groups of patients. The serum magnesium level is $<1.6 \mathrm{mg} / \mathrm{dl}$ among $52 \%$ of the patients belonging to Group A. This showed a significant p-value of $<0.001$ which is very significant (Table 5). Hence, the result shows that there is a significant decrease in the serum magnesium level among patients in Group A that is in patients with preterm onset of labor.

Table 6 represents the serum magnesium levels at different gestational ages among Group A patients that is patients who came in preterm labor. There is no significant difference noted in the serum magnesium levels according to POG, with a p-value of 0.126 , but majority of the patients belonging to very preterm with POG between 28-32+6 weeks had serum magnesium level <1.6 (Table 6). Table 7 and graph represent the serum magnesium level in Group B patients. No patients had a serum magnesium level below $1.6 \mathrm{mg} / \mathrm{dl}$. Majority that is $48 \%$ of the patients had serum magnesium level $>2.5 \mathrm{mg} / \mathrm{dl}$ (Table 7).

Among Group A patients, the mean the mean serum magnesium level noted is $1.59 \pm 0.83$ (Table 8). Among Group B patients, the mean serum magnesium level noted is 2.55 \pm 0.40 (Table 9). This shows a significant difference in the serum magnesium level among Group A and Group B patients that is the preterm and the term group of patients. This result is supported by the findings of many investigators, Puspo and Jagdish et al, found serum magnesium level in preterm labor $1.67 \pm 0.23$ $\mathrm{mg} / \mathrm{dl}$. Begum et al, also found serum magnesium $1.77 \pm 0.36$ in preterm labor. Kehinde et al, found mean serum magnesium level $1.73 \pm 0.4$ versus $1.93 \pm 0.4 \mathrm{mg} / \mathrm{dl}$. Among patients belonging to Group A who came in preterm labor corticosteroid prophylaxis could be achieved in $94 \%$ of the patients (Table 10). 
Table 6: Serum magnesium: Group A according to POG.

\begin{tabular}{|lllll|}
\hline Serum magnesium & POG in Group A & & & Total \\
& $\mathbf{2 8 - 3 2 + 6}$ weeks & $\mathbf{3 3 - 3 4 + 6}$ weeks & $\mathbf{3 5 - 3 6 + 6}$ weeks & $26(52 \%)$ \\
\hline$<1.6$ & $8(61.5 \%)$ & $1(20 \%)$ & $17(53.1 \%)$ & $3(6 \%)$ \\
\hline $1.6-2.0$ & $0(0 \%)$ & $1(20 \%)$ & $2(6.3 \%)$ & $12(24 \%)$ \\
\hline $2.0-2.5$ & $1(7.7 \%)$ & $3(60 \%)$ & $8(25 \%)$ & $9(18 \%)$ \\
\hline$>2.5$ & $4(30.8 \%)$ & $0(0 \%)$ & $5(15.6 \%)$ & $50(100 \%)$ \\
\hline Total & $13(100 \%)$ & $5(100 \%)$ & $32(100 \%)$ & \\
\hline
\end{tabular}

$\mathrm{p}=0.126$, not significant, fisher exact test

Table 7: Serum magnesium: Group B.

\begin{tabular}{|llll|}
\hline Serum magnesium & POG in Group B & & Total \\
\hline$<1.6$ & $\mathbf{3 7 - 3 8 + 6}$ weeks & $\mathbf{3 9 - 4 0}$ weeks & $0(0 \%)$ \\
\hline $1.6-2.0$ & $0(0 \%)$ & $0(0 \%)$ & $4(8 \%)$ \\
\hline $2.0-2.5$ & $2(6.9 \%)$ & $2(9.5 \%)$ & $22(44 \%)$ \\
\hline$>2.5$ & $15(51.7 \%)$ & $7(33.3 \%)$ & $24(48 \%)$ \\
\hline Total & $12(41.4 \%)$ & $12(57.1 \%)$ & $50(100 \%)$ \\
\hline
\end{tabular}

Table 8: The mean range of serum magnesium according to POG in Group A.

\begin{tabular}{|llllll|}
\hline Variables & POG in Group A & & & Total & p value \\
\hline Serum magnesium & $\mathbf{2 8 - 3 2 + 6}$ weeks & $\mathbf{3 3 - 3 4 + 6}$ weeks & $\mathbf{3 5 - 3 6 + 6}$ weeks & & 0.392 \\
\hline
\end{tabular}

Table 9: The mean range of serum magnesium according to POG in Group B.

\begin{tabular}{|c|c|c|c|c|c|}
\hline \multirow{2}{*}{ Variables } & \multicolumn{3}{|c|}{ POG in Group B } & \multirow{2}{*}{ Total } & \multirow{2}{*}{$\begin{array}{l}\text { p value } \\
37-38+6 \text { weeks }\end{array}$} \\
\hline & 37-38+6 weeks & 39-40 weeks & $35-36+6$ weeks & & \\
\hline Serum magnesium & $2.55 \pm 0.41$ & $2.55 \pm 0.39$ & $2.55 \pm 0.40$ & Serum magnesium & $2.55 \pm 0.41$ \\
\hline
\end{tabular}

Table 10: Corticosteroid prophylaxis in Group A.

\begin{tabular}{|lll|}
\hline $\begin{array}{l}\text { Prophylactic } \\
\text { cortico steroids }\end{array}$ & $\begin{array}{l}\text { No. of } \\
\text { patients }\end{array}$ & Percentage \\
\hline No & 3 & $6.0 \%$ \\
\hline Yes & 47 & $94.0 \%$ \\
\hline Total & 50 & $100 \%$ \\
\hline
\end{tabular}

Table 11: Outcome distribution of patients in Group A studied.

\begin{tabular}{|ll|l|}
\hline Outcome & Group A & Percentage \\
\hline Tocolysis achieved & 30 & $60.0 \%$ \\
\hline LSCS & 0 & $0.0 \%$ \\
\hline Delivered & 10 & $20.0 \%$ \\
\hline Discharged & 6 & $12.0 \%$ \\
\hline Tocolysis failed & 2 & $4.0 \%$ \\
\hline Vaginitis treated & 2 & $4.0 \%$ \\
\hline Total & 50 & $100.0 \%$ \\
\hline
\end{tabular}

The outcome has been studied among the patients belonging to Group-A is evaluated. Tocolysis could be achieved in $60 \%$ of the patients, $20 \%$ of the patients had spontaneous vaginal delivery, among 4\% tocolysis was failed and patients had vaginal delivery (Table 11).

\section{DISCUSSION}

The main focus of this current study is to compare the serum magnesium level in preterm labor and in term labor patients. Several studies have found the association between the serum magnesium levels and preterm labor.

The exact cause of hypomagnesemia in preterm labor is unknown but involvement of magnesium in many physiological and pathological processes have been detected in recent studies.

Past studies and reports have appeared to show a decreased level of serum magnesium in preterm labor. The present study has dealt with the concentration of serum magnesium in patients with preterm labor which is supposed to play an important role on the etiology of preterm labor if the serum magnesium level is low. In this study, the age of the women and parity compared between both the groups showed no significant differences and did not show any effect on the results of 
the study, similar to Kamal et al, and shahid et al, findings. The $\mathrm{p}$-value for age distribution is 0.142 (Table 1) which is not significant and the p-value for parity distribution is 0.915 (Table 2) which is also not significant between both the groups. In this study, there is no significant association of socio-economic status among both the groups, similar to Shahid et al, and Khani et al, study. On the contrary, studies conducted by Shakura et al, and Sharma et al, showed a significant difference among the cases and control based on socioeconomic status (Table 4).

In this study, the serum magnesium level is $<1.6$ in $52 \%$ of the patients in Group A, whereas in Group B there are no patients with serum magnesium <1.6 (Table 5). Tablerevealed a significant difference in serum magnesium levels among the preterm labor and term labor patients with a significant $\mathrm{p}$ value of $<0.001$. This shows that there is a significant role of serum magnesium level to detect preterm labor.

In this study, according to gestational age among the patients in Group A, the serum magnesium value is ranged. There is a low value of serum magnesium among early and late preterm patients, but among the patients between 33-34+6 weeks gestational age group, most of the patients had serum magnesium level more than 2 $\mathrm{mg} / \mathrm{dl}$. This may be due to a smaller number of patients belonging the gestational age between $33-34+6$ weeks of gestation and might require further studies to differentiate the level of serum magnesium level based on gestational age. Based on our study there is no significant difference noted in the serum magnesium level among different periods of gestation with a p-value of 0.126 (Table 6).

This table compares the mean serum magnesium levels in preterm labor. In present study, serum magnesium level has been estimated in 50 patients with preterm labor and 50 patients with term labor. It is found that serum magnesium level significantly reduced in the cases of preterm labor. Therefore, the finding in the current study demonstrated that serum magnesium concentration is decreased in preterm labor. In this study it is found that the patients belonging to preterm group have lower serum magnesium level than the patient with term gestation. In this study the mean magnesium was $1.59 \pm 0.83 \mathrm{mg} / \mathrm{dl}$ for the patients with preterm labor and $2.55 \pm 0.40 \mathrm{mg} / \mathrm{dl}$ for those with term labor. The mean difference was found to be statistically significant $(\mathrm{p}<0.001)$.

This result is found similar to the study findings of other investigators. In a study carried out by Puspo and Jagdish serum magnesium level in preterm labor was found to be $1.67 \pm 0.23 \mathrm{mg} / \mathrm{dl} .{ }^{15}$ Kurzel found that the patients with preterm labor had significantly depressed serum magnesium level and the mean was $1.60 \pm 0.466$. In a recent study by Kamal et al. ${ }^{6}$ Also found the mean serum magnesium level in preterm labor cases was 1.4 $\mathrm{mg} / \mathrm{dl} \pm 0.22 \mathrm{SD}$ and concluded that the estimation of serum magnesium may prove to be a valuable tool in predicting the preterm onset of labor. Begum et al, also observed that there was significant reduction $(\mathrm{p}<0.001)$ of serum magnesium (mean 1.77 \pm 0.36 ) in women with preterm labor. $^{18}$

Table 12: Comparison of this study to other studies.

\begin{tabular}{|lll|}
\hline Reference & Serum magnesium level - mg/dl (mean \pm SD) & p-value \\
\hline Kurzel RB et al $^{6}$ & $1.60 \pm 0.46$ & $<0.0005$ \\
\hline Pushpo D et al & & $<0.001$ \\
\hline Smolarczyk KR et al & 16 & $<0.003$ \\
\hline Wojcieka J et al $^{15}$ & $1.67 \pm 0.23$ & $<0.001$ \\
\hline Begum H et al $^{18}$ & $1.64 \pm 0.07$ & $<0.001$ \\
\hline Present study & $1.63 \pm 0.053$ & $<0.001$ \\
\hline
\end{tabular}

In this study, there is an overlap noted among both the case and control group in the serum magnesium range between $2-2.5 \mathrm{mg} / \mathrm{dl}$. But majority of the patients from Group A had a serum magnesium level $<1.6 \mathrm{mg} / \mathrm{dl}$ and majority of the patients in Group-B had a serum magnesium level $>2.5 \mathrm{mg} / \mathrm{dl}$. Hence, further studies are required to denote a normal range of serum magnesium level for preterm and term patients. In this study, there is no significant difference noted based on the gestational age, but the mean serum magnesium level noted at 28$32+6$ weeks of gestation was $1.41 \pm 0.97 \mathrm{mg} / \mathrm{dl}$ and at 35 $36+6$ weeks was $1.60 \pm 0.81$, but the mean serum magnesium level at 33-34+6 weeks was $2.01 \pm 0.49 \mathrm{mg} / \mathrm{dl}$.
This might be due to the less samples obtained from that particular gestational age of 33-34+6 weeks and might need further evaluation to come to a conclusion.

\section{CONCLUSION}

\section{From the present study, it may be concluded that:}

- Serum magnesium level was significantly low in women having preterm labor.

- There is no significant difference in serum magnesium level with age and parity was observed. 
- There is a significant difference in the range of serum magnesium level among patients in preterm labor and term labor.

- Above findings and analysis of this study suggests that the low serum Magnesium level is associated with preterm onset of labor.

- Hypomagnesaemia may be used as a predictor of preterm labor.

- Some predictive tests for preterm births are used but they still have poor sensitivities and are very expensive.

- Estimation of magnesium concentrations is relatively cheap.

- Magnesium supplementation may be considered in patients with decreased serum magnesium levels to prevent preterm labor.

- Low level of maternal serum magnesium is associated with adverse pregnancy outcomes, including preterm labor and low birth weight.

- Hence supplementation of oral magnesium can be considered in high risk patients as it can prevent preterm labor and it also helps in preventing low birth weight.

\section{ACKNOWLEDGMENTS}

Authors would like to thank all the patients who were the subject of this study, with whose co-operation this study was possible.

\section{Funding: No funding sources}

Conflict of interest: None declared

Ethical approval: The study was approved by the Institutional Ethics Committee

\section{REFERENCES}

1. Cunningham, Lenovo, Bloom, Hoffmann, Spong, Dashe, Casey, Sheffield Williams Obstetrics, $24^{\text {th }}$ ed; 2014: 829-833.

2. Kamal S, Sharan A, Kumar U, Shahi SK. Serum magnesium level in preterm labour. Indian J Pathol Microbiol. 2003;46(2):271-3.

3. Arias, Deftary, Bhide. Preterm parturition syndrome. Practical guide to high risk pregnancy and delivery: a South Asian Perspective, $3^{\text {rd }}$ Edition; 2008:193-204.

4. Lumley, J. Defining the problem: the epidemiology of preterm birth. Br J Obstet Gynaecol. 2003;110:37.
5. Peacock JL, Bland JM, Anderson HR. Preterm delivery; effect socioeconomic factors, psychological stress, smoking, alcohol, and cffeine. BMJ. 1995;311:531.

6. Kurzal RB. Serum magnesium level in pregnancy and preterm labour. Am J Perinatol. 1991;8:119-27.

7. Whitney EN, Cataldo CB, Rolfes SR. $6^{\text {th }}$ ed. Understanding normal and clinical nutrition, Belmont, CA: Wadsworth; 1996.

8. Jeroen HF, de Baaij, Hoenderop GJ, Bindels RJM. Magnesium in man: implication for health and disease. Physiol Reviews. 2015;95(1):1-46.

9. Griffin IJ. Encyclopedia of food sciences and nutrition (Second Edition); 2003: 3641.

10. Smith R. Parturition. N Engl J Med. 2007;365:27183.

11. Rosner B, Fundamentals of Biostatistics, $5^{\text {th }} \mathrm{ed}$, Duxbury; $2000: 80-240$

12. Riffenburg RH. Statistics in Medicine, $2^{\text {nd }}$ ed, Academic press; $2005: 85-125$.

13. Sunder Rao PSS, Richard J. An Introduction to Biostatistics, A manual for students in health sciences, New Delhi: Prentice hall of India. $4^{\text {th }}$ ed; 2006: 86-160.

14. Suresh KP, Chandrasekhar S. Sample Size estimation and Power analysis for clinical research studies. J Human Reprod Sci. 2012;5(1):7-13.

15. Pushpo D, Jagdish WMA. A study of serum magnesium level in preterm labour. J Obstet Gynaecol India. 1991;41:269-73.

16. Smolarczyk R, Wójcicka-Jagodzińska J, Romejko E, Piekarski P, Czajkowski K, Teliga J. Calciumphosphorus-magnesium homeostasis in women with threatened preterm delivery. Inter J Gynecol Obstet. 1997;57(1):43-8.

17. Wójcicka-Jagodzińska J, Romejko E, Piekarski P, Czajkowski K, Smolarczyk R, Lipiński T. Second trimester calcium-phosphorus-magnesium homeostasis in women with threatened preterm delivery. Int J Gynecol Obstet. 1998;61(2):121-5.

18. Begum H, Shamsuddin L, Khatun S. Relationship of preterm labour with serum magnesium level. Bangladesh J Obstet Gynaecol. 2004;19(1):3-6.

Cite this article as: Malathi T, Maddipati SS. A comparative study of serum magnesium levels in preterm labour and term labour. Int J Reprod Contracept Obstet Gynecol 2020;9:3291-6. 